\title{
HUBUNGAN ASUPAN VITAMIN C DAN TEKANAN DARAH PADA PEROKOK AKTIF USIA
} DEWASA AWAL

\author{
Fawnia Azalia ${ }^{1}$, Enny Probosari ${ }^{1}$, Martha Ardiaria ${ }^{1}$ \\ ${ }^{1}$ Departemen Ilmu Gizi, Fakultas Kedokteran, Universitas Diponegoro \\ Jln. Prof. H. Soedarto, SH., Semarang, Telp (024) 76402881, Email : gizifk@undip.ac.id
}

\begin{abstract}
Background: Hypertension is a condition affects to various disease complications. One of the nutrients related to blood pressure is vitamin $C$ that has an antioxidant activity. This study aims to determine the association between vitamin $C$ intake with blood pressure in young adult active smokers. Confounding variables include intake of vitamin E, sodium, and calcium.

Method: This research was an observational research with cross-sectional study design. Subjects were selected using purposive sampling involving 51 active cigarrate smokers at young adult age based on inclusion criteria. Vitamin $C$ intake was assessed by SQ-FFQ. Blood pressure were measured by digital sphygmomanometer. Rank-Spearman Correlation was used to analyze correlation of vitamin $C$ intake with blood pressure.

Result: The median of systolic blood pressure was $122 \mathrm{mmHg}$ and mean of diastolic blood pressure was 80.45 $\pm 10,15$ $\mathrm{mmHg}$. Median of vitamin C intake was 76,4 mg. There was no correlation between vitamin C intake and systolic blood pressure ( $p$ value $=0,91)$ and diastolic blood pressure $(p$ value $=0,33)$ in active cigarrate smoker at young adult age. Conclusion: There is no correlation between vitamin $C$ intake and blood pressure in active cigarrate smoker at young adult age.
\end{abstract}

Key Words: vitamin C, blood pressure, active cigarrate smoker, young-adult age

\begin{abstract}
ABSTRAK
Latar Belakang: Hipertensi adalah kondisi yang berdampak pada berbagai komplikasi penyakit. Salah satu zat gizi yang berpengaruh terhadap tekanan darah adalah vitamin C. Vitamin $C$ merupakan salah satu antioksidan yang dapat menyebabkan proses remodelling pada pembuluh darah. Penelitian ini bertujuan untuk mengetahui hubungan asupan vitamin $C$ dan tekanan darah pada perokok aktif usia dewasa awal. Variabel perancu dalam penelitian ini diantaranya asupan vitamin E, natrium, dan kalsium.

Metode: Penelitian observasional dengan rancangan cross-sectional dilakukan dengan pemilihan subjek menggunakan purposive sampling yang melibatkan 51 perokok aktif berdasarkan kriteria inklusi. Data asupan diperoleh menggunakan $S Q-F F Q$. Tekanan darah diukur menggunakan tensimeter digital. Analisis hubungan asupan vitamin $C$ dan tekanan darah dengan uji korelasi Rank-Spearman.

Hasil: Penelitian ini menunjukkan median tekanan darah sistolik sebesar $122 \mathrm{mmHg}$ dan rerata tekanan darah diastolik sebesar 80,45 $\pm 10,15 \mathrm{mmHg}$. Median asupan vitamin C sebesar 76,4 mg. Tidak terdapat hubungan yang bermakna antara asupan vitamin $C$ dan tekanan darah sistolik pada perokok aktif usia dewasa awal $(p$ value $=0,91)$ dan tekanan darah diastolik ( $p$ value $=0,33)$.
\end{abstract}

Simpulan: Tidak terdapat hubungan asupan vitamin C dan tekanan darah pada perokok aktif usia dewasa awal.

Kata Kunci: Vitamin C, Tekanan Darah, Perokok, Dewasa Awal

\section{PENDAHULUAN}

Hipertensi atau tingginya tekanan darah adalah kondisi yang dapat berdampak pada berbagai komplikasi penyakit. ${ }^{1}$ Hipertensi masih merupakan tantangan besar di Indonesia karena merupakan masalah kesehatan yang kerap kali ditemukan pada pelayanan kesehatan primer yaitu sebanyak $13,1 \%$ dari total kunjungan. Angka kematian akibat hipertensi di seluruh dunia mencapai 13\% setiap tahunnya. ${ }^{2}$ Prevalensi hipertensi pada penduduk usia 18 tahun ke atas di Indonesia pada tahun 2013 sebesar $25,8 \%$. $^{3}$

Merokok diketahui dapat mengakibatkan hipertensi melalui mekanisme melemahkan sistem pertahanan antioksidan dan melalui produksi ROS. Penelitian menunjukkan bahwa enam hembusan rokok mampu mendeplesikan kadar vitamin C plasma dalam tubuh. Prevalensi merokok di Indonesia kelompok usia diatas 15 tahun meningkat dari tahun ke tahun, yaitu 34,2\% pada tahun 2007 menjadi $36,3 \%$ pada tahun 2013, serta presentase pengguna rokok tahun 2013 sebanyak 64,9\% pada laki-laki dan $2,1 \%$ pada perempuan. ${ }^{4}$ Jawa Tengah termasuk 5 besar tertinggi untuk prevalensi kelompok usia 15 tahun ke atas yang merokok yaitu sebesar $25,3 \% .^{5}$

Nikotin pada rokok berkontribusi terhadap pembentukan radikal bebas yang berasal dari oksigen yaitu anion superoksida. ${ }^{6}$ Anion superoksida dapat 
mengikat nitric oxide yang memiliki fungsi vasodilatasi endotelium dan pengaturan inflamasi yang kemudian menyebabkan terbentuknya ROS dan penurunan kadar NO pada vaskular. Penurunan kadar NO mengakibatkan disfungsi endotel dan kemudian berdampak pada hipertensi. ${ }^{7,8}$

Vitamin C merupakan salah satu antioksidan yang dapat menyebabkan proses remodelling pada pembuluh darah sehingga dapat menyebabkan vasodilatasi pada pembuluh darah yang mengalami vasokontriksi. ${ }^{9}$ Vitamin $\mathrm{C}$ merupakan water-soluble scavenger dari radikal bebas yang kuat, dapat menurunkan adhesi monosit terhadap sel endotel, mengurangi inaktivasi NO dan merangsang aktivasi eNOS. ${ }^{10}$ Vitamin $\mathrm{C}$ terdapat pada berbagai sumber alami, seperti buah segar dan sayuran. Sumber vitamin $C$ lainnya berasal dari organ hati hewan. ${ }^{11}$ Studi menunjukkan peningkatan asupan buah dan sayur pada subjek yang mengalami hipertensi selama 6 bulan mengakibatkan peningkatan blood antioxidant capacity dan penurunan tekanan darah sistolik maupun diastolik. ${ }^{12}$

Berdasarkan penjelasan yang diuraikan sebelumnya, peneliti ingin mengkaji hubungan asupan vitamin $\mathrm{C}$ dan tekanan darah pada perokok aktif usia dewasa awal. Tujuan penelitian ini adalah untuk mengetahui hubungan asupan vitamin $\mathrm{C}$ dan tekanan darah pada perokok aktif usia dewasa awal.

\section{METODE}

Penelitian ini termasuk dalam ruang lingkup keilmuan gizi masyarakat. Jenis penelitian yang dilakukan yaitu cross sectional dimana variabel yang diteliti diambil pada waktu bersamaan. Penelitian dilaksanakan pada bulan April 2018 berlokasi di sekitar kampus Universitas Diponegoro, Semarang.

Pemilihan subjek penelitian dilakukan menggunakan metode purposive random sampling. Kriteria inklusi sampel meliputi bersedia menjadi subjek penelitian dengan mengisi informed consent, berusia 18-25 tahun, subjek memiliki IMT underweight atau normal, tidak mengonsumsi obatobatan hipertensiantidiuretik, beta bloker, vasodilator, inhibitor saraf simpatik, antagonis kalsium, dan enzim konveksi angiotensin dan alpha bloker, subjek merupakan perokok aktif yang merokok setiap hari dalam jangka waktu minimal 6 bulan, dan subjek tidak mengkonsumsi alkohol. Kriteria eksklusi pada penelitian ini meliputi subjek menderita penyakit jantung bawaan, penyakit ginjal, dan hipertiroid, sakit yang menyebabkan tidak bisa beraktivitas atau meninggal dunia ketika proses penelitian berlangsung, serta subjek mengundurkan diri dalam penelitian.

Besar sampel pada penelitian ini sebesar 46 sampel dengan perhitungan untuk menghindari $d r o p$ out maka dilakukan perhitungan koreksi dengan perkiraan proporsi drop out sebesar 10\%, sehingga besar subjek penelitian ini adalah 51 orang. Variabel bebas dalam penelitian ini adalah asupan vitamin $\mathrm{C}$ sedangkan variabel terikat adalah tekanan darah sistolik dan diastolik, serta variabel perancu pada penelitian ini adalah asupan vitamin E, asupan natrium, dan asupan kalsium. Data yang dikumpulkan meliputi data umum subjek, data antropometri, data asupan dan data tekanan darah subjek.

Skrining yang dilakukan berupa wawancara mengenai riwayat merokok, pengukuran tinggi badan menggunakan microtoise dengan ketelitian $0,1 \mathrm{~cm}$; berat badan menggunakan timbangan digital yang telah dikalibrasi dengan ketelitian $0,1 \mathrm{~kg}$; untuk mendapatkan sampel terpilih. Data antropometri diperlukan untuk menentukan Indeks Massa Tubuh (IMT) subjek, serta data riwayat merokok untuk mengetahui subjek penelitian termasuk perokok aktif. Data tekanan darah diperoleh melalui tensimeter digital. Dari 66 subjek yang diskrining, diperoleh 51 sampel yang memenuhi kriteria inklusi.

Data asupan diperoleh melalui wawancara asupan dengan semi quantitative-food frequency (SQFFQ). Wawancara ini untuk mengetahui jenis dan jumlah makanan yang dikonsumsi oleh subjek penelitian selama satu bulan terakhir. Asupan vitamin $\mathrm{C}$ merupakan rata-rata miligram/hari asupan vitamin $\mathrm{C}$ yang bersumber dari makanan atau minuman. Data asupan vitamin E, natrium, dan kalsium merupakan rata-rata miligram/hari asupan vitamin $\mathrm{E}$, natrium, dan kalsium yang bersumber dari makanan atau minuman.

Pengolahan dan analisis data penelitian ini menggunakan program Nutrisurvery 2007 dan software perhitungan statistik. Analisis univariat digunakan untuk mendeskripsikan data subjek penelitian yang ditampilkan dalam tabel distribusi frekuensi. Uji normalitas menggunakan KolmogorovSmirnoff. Analisis bivariat untuk mengetahui hubungan asupan vitamin $\mathrm{C}$ dengan tekanan darah pada perokok menggunakan uji korelasi Pearson jika data berdistribusi normal dan uji korelasi RankSpearman jika data berdistribusi tidak normal.

Tabel 1. Gambaran Usia dan Status Gizi Subjek

\begin{tabular}{lcc}
\hline Karakteristik & Frekuensi & \% \\
\hline Usia & & \\
18-22 tahun & 36 & $70,6 \%$ \\
23-25 tahun & 15 & $29,4 \%$ \\
Status Gizi & & \\
Underweight & 14 & $27,6 \%$ \\
Normal & 37 & $72,6 \%$ \\
\hline
\end{tabular}




\section{HASIL}

Penelitian ini diawali dengan skrining terhadap 66 perokok aktif usia 18-25 tahun di Kota Semarang. Dari skrining tersebut diperoleh sampel yang memenuhi kriteria inklusi dan eksklusi sebanyak 51 orang. Berdasarkan hasil skrining, didapatkan data karakteristik subjek, data tekanan darah subjek, dan data asupan subjek. Data karakteristik subjek penelitian terdiri dari usia dan status gizi ditampilkan pada Tabel 1.

Sebanyak 51 sampel penelitian perokok aktif dengan usia 18-25 tahun. Tabel 1 menunjukkan bahwa pada penelitian ini karakteristik usia dengan frekuensi terbesar pada usia 18-22 tahun (70,6\%). Sementara, status gizi subjek berdasarkan indikator IMT didominasi oleh status gizi normal $(72,6 \%)$.

Tabel 2. Karakteristik Variabel Penelitian

\begin{tabular}{lrrr}
\hline \multicolumn{1}{c}{ Variabel } & Rerata/Median & Minimal & Maksimal \\
\hline Tekanan darah sistolik (mmHg) & $122^{\mathrm{a}}$ & 92 & 153 \\
Tekanan darah diastolik (mmHg) & $80.45 \pm 10.1^{\mathrm{b}}$ & 58 & 115 \\
Asupan & & & \\
Vitamin C (mg) & $76.4^{\mathrm{a}}$ & 8.8 & 519.6 \\
Vitamin E (mg) & $5.5^{\mathrm{a}}$ & 1.0 & 24.6 \\
Natrium (mg) & $532.3 \pm 3.14^{\mathrm{b}}$ & 133.9 & 1341.5 \\
Kalsium (mg) & $554.9^{\mathrm{a}}$ & 161.3 & 1676.5 \\
\hline
\end{tabular}

${ }^{\mathrm{a}}$ Median, ${ }^{\mathrm{b}}$ Rerata \pm SD

Pada tabel 2 menunjukkan median tekanan darah sistolik adalah $122 \mathrm{mmHg}$ dan rerata tekanan darah diastolik adalah 80,45 $\pm 10,1 \mathrm{mmHg}$. Rerata/median variabel asupan terbagi menjadi beberapa kategori, diantaranya asupan vitamin $\mathrm{C}$ yang tergolong normal, asupan vitamin $\mathrm{E}$, natrium, dan kalsium yang tergolong rendah. Data distribusi frekuensi data asupan dapat dilihat pada Tabel 3.

Tabel 3. Karakteristik Variabel Penelitian

\begin{tabular}{lcr}
\hline Karakteristik Perokok & N & \% \\
\hline Lama Merokok & 37 & 72,55 \\
$\leq 2$ tahun & 11 & 21,57 \\
$\leq 4$ tahun & 3 & 5,88 \\
$\leq 6$ tahun & & \\
Jenis Rokok & 35 & 68,63 \\
Filter & 16 & 31,37 \\
Kretek & & \\
& & \\
Jumlah Rokok (Hari) & 14 & 27,45 \\
$1-4$ & 29 & 56,86 \\
$5-8$ & 8 & 15,69 \\
$9-14$ & & \\
\hline
\end{tabular}

Tabel 3. menunjukkan bahwa sebagian besar subjek penelitian lama merokok $\leq 2$ tahun $(72,55 \%)$ dengan jenis rokok yang paling dominan adalah rokok filter $(68,63 \%)$ dan jumlah rokok per hari didominasi oleh 5-8 batang per hari $(56,86 \%)$.

Tabel 4. Karakteristik Variabel Penelitian

\begin{tabular}{lcr}
\hline Tekanan Darah & N & \% \\
\hline Normal & 49 & 96,08 \\
Hipertensi & 2 & 3,92 \\
\hline
\end{tabular}

Tabel 4. menunjukkan bahwa sebagian besar subjek penelitian memiliki tekanan darah normal $(96,08 \%)$

Tabel 5. Distribusi Frekuensi Data Asupan

\begin{tabular}{lcr}
\hline Variabel & N & \% \\
\hline Vitamin C & & \\
Kurang & 23 & 45,1 \\
Baik & 28 & 50,9 \\
& & \\
Vitamin E & & \\
Kurang & 49 & 96,1 \\
Baik & 2 & 3,9 \\
& & \\
Natrium & & \\
Kurang & 50 & 98,0 \\
Baik & 1 & 2,0 \\
& & \\
Kalsium & & 74,5 \\
Kurang & 39 & 9,8 \\
Baik & 5 & 13,7 \\
Lebih & 7 & \\
\hline
\end{tabular}

Tabel 4. menunjukkan bahwa sebagian besar asupan sampel tergolong dalam kategori kurang, diantaranya vitamin $\mathrm{E}(96,1 \%)$, natrium $(98,0 \%)$, dan asupan kalsium $(74,5 \%)$. Asupan vitamin $\mathrm{C}$ tergolong didominasi oleh kategori baik (50,9\%).

Tabel 5, menunjukkan bahwa tidak terdapat hubungan antara asupan vitamin $\mathrm{C}$, vitamin $\mathrm{E}$, natrium, dan kalsium terhadap tekanan darah sistolik.

Tabel 6. menunjukkan bahwa tidak terdapat hubungan antara asupan vitamin $\mathrm{C}$, vitamin $\mathrm{E}$, natrium, dan kalsium dan tekanan darah diastolik. 
Tabel 6. Hubungan Asupan dan Tekanan Darah Sistolik

\begin{tabular}{lcc}
\hline \multicolumn{1}{c}{ Variabel } & \multicolumn{2}{c}{ Tekanan Darah Sistolik } \\
\cline { 2 - 3 } & $\boldsymbol{p}$ & $\mathbf{r}$ \\
\hline Asupan & $0,910^{\mathrm{a}}$ & $-0,016$ \\
Vitamin C (mg) & $0,821^{\mathrm{a}}$ & $-0,032$ \\
Vitamin E (g) & $0,682^{\mathrm{a}}$ & 0,059 \\
Natrium (g) & $0,808^{\mathrm{a}}$ & $-0,035$ \\
Kalsium (g) & &
\end{tabular}

aji Rank-Spearman

Tabel 7. Hubungan Asupan dan Tekanan Darah Diastolik

\begin{tabular}{lcc}
\hline \multicolumn{1}{c}{ Variabel } & \multicolumn{2}{c}{ Tekanan Darah Diastolik } \\
\cline { 2 - 3 } & $\boldsymbol{p}$ & $\mathbf{r}$ \\
\hline Asupan & & \\
Vitamin C (mg) & $0,330^{\mathrm{a}}$ & $-0,139$ \\
Vitamin E (g) & $0,616^{\mathrm{a}}$ & $-0,072$ \\
Natrium (g) & $0,217^{\mathrm{b}}$ & $-0,176$ \\
Kalsium (g) & $0,134^{\mathrm{a}}$ & $-0,213$ \\
\hline
\end{tabular}

${ }^{\mathrm{a} U j i}$ Rank-Spearman; ${ }^{\mathrm{b}} \mathrm{Uji}$ Pearson

\section{PEMBAHASAN}

Berdasarkan hasil skrining yang dilakukan pada perokok aktif usia dewasa awal di Kota Semarang dengan sampel sebesar 51 subjek penelitian yang memenuhi kriteria inklusi dan eksklusi terdiri dari status gizi underweight $(27,6 \%)$ dan status gizi normal $(72,6 \%)$. Pada penelitian ini diketahui frekuensi terbesar berdasar kategori usia adalah pada usia $18-22$ tahun $(70,6 \%)$. Pada usia ini terjadi beberapa perubahan yaitu perubahan biologis dan psikologi. ${ }^{13}$ Usia ini merupakan masa yang ditandai dengan upaya pencarian identitas diri, peran dan tanggung jawab dalam masyarakat dan tujuan hidup. Usia ini diharapkan mampu menyelesaikan periode pencarian identitas diri sehingga muncul eksplorasi dan komitmen untuk pembentukan jati diri. ${ }^{14}$ Penelitian ini diketahui subjek penelitian yang dilakukan skrining terkait riwayat merokok sebagian besar menghisap rokok sebanyak 6 batang per hari dengan rokok jenis filter. Penelitian yang dilakukan oleh Amri Aji dan kawan-kawan menunjukkan bahwa rokok jenis filter terdapat kandungan nikotin yang lebih sedikit bila dibandingkan dengan rokok kretek. ${ }^{15}$

Vitamin C merupakan antioksidan memiliki peran pada neurotransmiter yang dapat berkontribusi pada aktivitas anti-hipertensi. ${ }^{16}$ Vitamin $\mathrm{C}$ adalah scavenger radikal bebas yang dapat membantu menetralkan beban oksidan. Fungsi vitamin C sebagai antioksidan adalah dengan mencegah substansi mengalami oksidasi dengan cara melakukan donor elektron. Mekanisme reduksi kadar vitamin C pada perokok adalah akibat adanya oksidasi yang berlangsung secara cepat karena adanya radikal bebas. ${ }^{17}$ Vitamin $\mathrm{C}$ merupakan salah satu antioksidan yang dapat menyebabkan proses remodelling pada pembuluh darah sehingga dapat menyebabkan vasodilatasi pada pembuluh darah yang mengalami vasokontriksi. ${ }^{9}$ Vitamin $\mathrm{C}$ merupakan water-soluble scavenger dari radikal bebas yang kuat, dapat menurunkan adhesi monosit terhadap sel endotel, mengurangi inaktivasi NO dan merangsang aktivasi eNOS. $^{10}$

Merokok meningkatkan stres oksidatif tidak hanya melalui produksi ROS namun juga dengan melemahkan sistem pertahanan antioksidan. ${ }^{18}$ Perokok diketahui mengonsumsi makanan rendah vitamin $\mathrm{C}$ bila dibandingkan dengan non perokok yaitu yang bersumber dari sayur dan buah, serta perokok mengonsumsi makanan yang cenderung sedikit baik jumlah makan per hari dan porsi makanan setiap makan yang menyebabkan rendahnya konsentrasi plasma antioksidan ${ }^{18,19}$. Hal ini sebagai akibat nikotin pada perokok yang berpengaruh pada Central Nervous System yang menekan nafsu makan. ${ }^{20}$

Merokok memiliki peran penting dalam merusak keseimbangan antioksidan. ${ }^{17}$ Radikal bebas dikendalikan oleh tingkat antioksidan, sedangkan ketika antioksidan tidak cukup dalam mengkompensasi radikal bebas yang berlebihan maka dapat menyebabkan stres oksidatif pada jantung. ${ }^{21}$

Hubungan antara ROS dan NO memiliki terjadinya hipertensi pada perokok. Penurunan bioavailabilitas nitric oxide (NO) dan peningkatan produksi dari reactive oxygen species (ROS) dapat menyebabkan terjadinya disfungsi endotelium. Defisit NO yang terjadi dapat mempercepat proses atherosklerosis. Aktivitas biologis NO ditentukan oleh radikal bebas yang berasal dari oksigen, seperti anion superoksida yang dapat dengan cepat mengikat $\mathrm{NO}$ membentuk peroxynitrite ( $\left.\mathrm{ONOO}^{-}\right)$. Peroxynitrite ( $\mathrm{ONOO}^{-}$) dapat melepaskan endothelial nitric oxide synthase (eNOS), sehingga menyebabkan enzim anti atherosklerosis yaitu enzim yang memproduksi NO menjadi enzim yang memproduksi reactive oxygen species (ROS). Pelepasan eNOS dapat mengakibatkan menurunnya kadar NO pada vaskular dan mengakibatkan disfungsi endotel dan perubahan nada vaskular yang kemudian berdampak pada hipertensi. ROS dapat bereaksi secara langsung dengan NO yaitu mereduksi biovailabilitas NO. Perubahan keadaan NO ini berakibat meningkatkan nada vaskular dan tekanan darah. ${ }^{7,8}$

Penelitian ini menunjukkan asupan vitamin $\mathrm{C}$ tidak terbukti berkaitan dengan takanan darah sistolik ( $p$ value $=0,91)$ dan tekanan darah diastolik ( $p$ value $=0,33)$. Hal ini sesuai dengan penelitian yang dilakukan oleh Jo"el Pincemail dan kawan-kawan yang menyatakan bahwa tidak terdapat dampak yang 
relevan terhadap tekanan darah hingga tingkat plasma vitamin C. ${ }^{22}$ Ketidaksesuaian hasil penelitian ini dapat disebabkan karena Teori Wear and Tear. Teori ini mengatakan bahwa tubuh dan sel pada tubuh dapat mengalami kerusakan akibat penggunaan yang berlebihan karena toksin yang ada pada makanan maupun lingkungan. ${ }^{23}$ Teori ini juga menyatakan bahwa pada saat muda, tubuh masih mampu melakukan kompensasi terhadap pengaruh buruk dari luar. ${ }^{24}$ Teori lain yang mendukung hal ini adalah Teori Neuroendokrin. Hormon bersifat vital dalam mengatur dan memperbaiki fungsi tubuh. Pada usia muda berbagai hormon bekerja dengan baik untuk mengatur fungsi tubuh. Teori ini menyatakan bahwa saat muda level hormon cenderung tinggi, seiring bertambahnya usia tubuh memproduksi hormon yang lebih sedikit. Hal ini dapat menyebabkan gangguan terkait fungsi tubuh. Hormon berperan dalam memperbaiki dan mengatur fungsi tubuh, jika terjadi penurunan produksi hormon akibat usia dapat menyebabkan penurunan kemampuan tubuh dalam memperbaiki dan mengatur fungsi tubuh. ${ }^{23}$

Pada penelitian ini, seluruh variabel perancu dalam penelitian ini juga tidak terbukti berkaitan tekanan darah sistolik maupun diastolik $(\rho>0,05)$. Variabel perancu yang pertama adalah asupan vitamin E. Vitamin E memiliki cara kerja yang sama dengan vitamin $\mathrm{C}$, yaitu menangkap radikal bebas dan mencegah terjadinya reaksi berantai. ${ }^{25}$ Pada penelitian ini diketahui tidak terdapat hubungan antara asupan vitamin E dengan tekanan darah sistolik ( $p$ value $=0,821)$ dan tekanan darah diastolik ( $p$ value $=0,616$ ). Hal ini sesuai dengan studi yang dilakukan Chen dan kawan-kawan yang menunjukkan bahwa tidak ada kejadian mengenai hubungan antara tekanan darah dan asupan dari karoten maupun vitamin E. Hubungan secara signifikan terjadi antara hipertensi dengan level serum vitamin $\mathrm{A}, \mathrm{E}$ dan $\beta$-karoten setelah mengontrol faktor lain seperti usia, jenis kelamin, etnis, pendidikan, indeks massa tubuh, konsumsi alkohol, riwayat diabetes, asupan natrium, kalium, lemak jenuh, total asupan energi per hari. Ketidaksesuaian ini dapat terjadi akibat nilai asupan subjek penelitian yang kurang $(96,1 \%)$. American Institute of Nutrition mengatakan bahwa jumlah rekomendasi asupan per hari untuk vitamin $\mathrm{E}$ pada manusia adalah sebesar 30 IU/hari atau $0,43 \mathrm{IU} / \mathrm{kg} / \mathrm{hari}$. Penyebab lain yang mungkin terjadi adalah karena vitamin $\mathrm{E}$ dapat menjadi radikal bebas dalam tubuh, walaupun vitamin $\mathrm{C}$ dapat mengubah radikal vitamin $\mathrm{E}$ prooksidan kembali ke vitamin E. ${ }^{26}$ Variabel perancu berikutnya adalah natrium. Pada penelitian ini diketahui tidak terdapat hubungan antara asupan natrium dan tekanan darah sistolik $(p$ value $=0,682$ ) dan tekanan darah diastolik ( $p$ value $=0,217$ ).
Natrium dan kalium merupakan mineral makro yang mempunyai hubungan erat dalam berbagai jaringan tubuh. Sebuah penelitian menunjukkan bahwa peningkatan kejadian hipertensi berkaitan dengan perubahan rasio natrium dan kalium dalam makanan yang dikonsumsi. Rasio Na:K yang dianjurkan adalah 1:1. ${ }^{27}$ Hal ini menjadi keterbatasan penelitian karena tidak mengkaji rasio dari asupan natrium dan kalium. Variabel perancu lain dari penelitian ini adalah asupan kalsium. Pada penelitian ini diketahui bahwa tidak terdapat hubungan antara konsumsi kalsium dan tekanan darah sistolik ( $p$ value $=0,808$ ) dan tekanan darah diastolik ( $p$ value $=0,134)$. Asupan kalsium subjek dalam penelitian ini dominan tergolong rendah (74,5\%). Jika asupan kalsium kurang dari kebutuhan tubuh maka untuk menjaga keseimbangan kalsium di dalam darah, hormon paratiroid menstimulasi pengeluaran kalsium dari tulang dan masuk ke darah. Kalsium dalam darah akan mengikat asam lemak bebas sehingga pembuluh darah menjadi menebal dan mengeras sehingga dapat mengurangi elastisitas jantung yang akan meningkatkan tekanan darah. Hal lain yang dapat terjadi adalah terkait dengan faktor lain seperti faktor genetik yang bervariasi. Faktor genetik ini mempengaruhi kemampuan tubuh menggunakan kalsium secara optimal untuk menurunkan tekanan darah dan adanya faktor-faktor yang menghambat absorbsi kalsium di usus halus seperti fosfor, oksalat, dan serat yang dapat menjadi penyebab tidak optimalnya fungsi kalsium dalam menurunkan tekanan darah. ${ }^{28}$

Penelitian ini menunjukkan baik variabel dependen maupun variabel perancu, tidak memiliki hubungan dengan tekanan darah baik sistolik maupun diastolik pada perokok aktif usia dewasa awal. Penelitian ini mengkaji dengan subjek penelitian dewasa awal dengan fisiologis yang masih baik. Usia ini diketahui organ tubuh dapat memperbaiki dan mengatur fungsinya agar berfungsi optimal, sehingga tubuh dapat mengkompensasi kemudian memperbaiki dan mengatur fungsi tubuh agar berfungsi dengan baik sesuai dengan Teori Wear and Tear serta Teori Neuroendokrin. ${ }^{23}$ Penelitian ini mengkaji dengan jumlah sampel yang kurang besar. Semakin besar sampel kemungkinan akan lebih tepat menggambarkan populasinya ${ }^{29}$. Penelitian ini juga diketahui data tidak bervariasi pada tekanan darah sehingga analisis dapat menunjukkan tidak ada hubungan antara asupan vitamin $\mathrm{C}$ dan tekanan darah. Pada penelitian ini terdapat beberapa faktor lain yang berpengaruh terhadap tekanan darah namun tidak diteliti akibat keterbatasan penelitian. Faktor lain yang berpengaruh tersebut diantaranya asupan makronutrien, mikromineral kalium dan magnesium, antioksidan polifenol, aktivitas fisik, stres, dan durasi tidur. 


\section{SIMPULAN}

Penelitian ini membuktikan bahwa tidak terdapat hubungan asupan vitamin $\mathrm{C}$ dan tekanan darah sistolik $(p=0,91)$ serta tekanan darah diastolik $(p=0,33)$ pada perokok aktif usia dewasa awal.

\section{SARAN}

Penelitian yang mengkaji keterkaitan antara asupan vitamin $\mathrm{C}$ dan tekanan darah menggunakan sampel yang tergolong sedikit, sehingga diperlukan penelitian lebih lanjut mengenai hubungan asupan vitamin $\mathrm{C}$ dan tekanan darah dengan jumlah sampel yang lebih besar untuk lebih menggambarkan populasi. Penelitian yang selanjutnya juga diharapkan dapat meneliti lebih banyak variabel perancu yang berhubungan dengan tekanan darah agar hasil yang didapatkan lebih akurat.

Masyarakat diharapkan tetap menjaga hidup sehat dan mengkonsumsi makanan dengan sumber antioksidan. Penelitian ini diketahui tidak terdapat hubungan antara asupan vitamin $\mathrm{C}$ dan tekanan darah pada perokok aktif usia dewasa awal, hal ini akibat fisiologis tubuh pada usia dewasa awal yang masih baik dalam mengkompensasi pengaruh buruk dari luar, namun apabila tubuh terpapar pengaruh buruk secara terus menerus, kemampuan tubuh dalam mengkompensasi hal ini dapat berkurang dan dapat sebagai faktor risiko timbul masalah kesehatan.

\section{UCAPAN TERIMAKASIH}

Puji syukur penulis sampaikan ke hadirat Allah SWT atas segala ridho dan rahmat yang telah diberikan kepada penulis. Terimakasih kepada seluruh subjek penelitian serta pihak-pihak yang telah membantu berjalannya penelitian ini.

\section{DAFTAR PUSTAKA}

1 Siyad A. Hypertension. Hygeia J Drugs Med 2011; 3: 1-16.

2 Peltzer K, Phaswana-Mafuya N. Hypertension and Associated Factors in Older Adults in South Africa. Cardiovasc J Afr 2013; 24: 67-72.

3 Kementerian Kesehatan RI. Pusat Data dan Informasi Kementerian Kesehatan RI. Jakarta, 2014.

4 Badan Penelitian dan Pengembangan Kesehatan. Riset Kesehatan Dasar (RISKESDAS) 2013. Jakarta, 2013.

5 Badan Penelitian dan Pengembangan Kesehatan. Riset Kesehatan Dasar (RISKESDAS) 2010. Jakarta, 2010.

6 Valavanidis A, Vlachogianni T, Fiotakis K. Tobacco Smoke: Involvement of Reactive Oxygen Species and Stable Free Radicals in Mechanisms of Oxidative Damage,
Carcinogenesis and Synergistic Effects with Other Respirable Particles. Int J Environ Res Public Health 2009; 6: 445-462.

7 Meera S. Oxidative Imbalance in Smokers with and without Hypertension. Biomed Res 2011; 22: 267-272.

8 Schulz E, Gori T, Mu T. Oxidative Stress and Endothelial Dysfunction in Hypertension. 2011; : 665-673.

9 Lestari EP, Bakar A, Hidayati L. Regulasi Tekanan Darah pada Penderita Hipertensi Primer dengan Smoothie Pisang (Musa paradisiaca). J Ners 2017; 6 .

10 Ramadhani IP. Hubungan Konsumsi Makanan yang Mengandung Antioksidan dengan Tekanan Darah pada Masyarakat Minang Kabau di Sumatera Barat [Skripsi]. Padang: Universitas Andalas; 2011.

11 Devaki SJ, Raveendran RL. Vitamin C: Sources, Functions, Sensing and Analysis. In: Hamza AH (ed). Vitamin C. InTech, 2017 doi:10.5772/intechopen.70162.

12 Ardalan MR, Rafieian-Kopaei M. Antioxidant Supplementation in Hypertension. J Ren Inj Prev 2014; 3: 39-40.

13 Apriana K. Gambaran Kebiasaan Merokok dengan Profil Tekanan Darah pada Mahasiswa Perokok Laki-Laki Usia 18-22 Tahun (Studi Kasus di Fakultas Teknik Jurusan Geologi Universitas Diponegoro Semarang). J Kesehat Masy 2012; 1: 251-261.

14 Nasrudin E. Hubungan antara Gaya Pengasuhan Orang Tua Tipe, Enabling, dan Constraining dengan Komitmen dan Pembentukan Status Identitas Keberagaman Remaja Akhir. J Ilm Psikol Pendidik dan Perkemb 2008; I: 1-16.

15 Aji A, Maulinda L, Amin S. Isolasi Nikotin dari Puntung Rokok sebagai Insektisida. J Teknol Kim Unimal 2015; 4: 100-120.

16 Afrose SA, Fahmeed A, Mujtaba A, Khan M, Noorulla SM. A Study on Effects of Combining Vitamin $\mathbf{C}$ with Hypertension Therapy. Int $\mathbf{J}$ Pharm Res Aliied Sci 2015; 4: 142-146.

17 Nagaraj, D SK, Paunipagar P V. Study of Serum Malondialdehyde and Vitamin C in Smokers. J Sci Innov Res 2014; 3: 569-571.

18 Shankar H, Selvam TTP. A Comparative Study of Antioxidants in Smokers Non-Smokers. Asia Pacific J Res 2016; 1: 6.

19 Pellegrino D. Antioxidants and Cardiovascular Risk Factors. Diseases 2016; 4: 1-9.

20 Maw W, Mon AA, Misebah MH Bin, Naidu S, Sutheskumar. Vitamin C Intake in Smokers. SEGi Rev 2012; 5: 157-161.

21 Zhang PY, Xu X, Li XC. Cardiovascular Diseases: Oxidative Damage and Antioxidant 
Protection. Eur Rev Med Pharmacol Sci 2014; 18: 3091-3096.

22 Pincemail J, Vanbelle S, Degrune F, CheramyBien JP, Charlier C, Chapelle JP et al. Lifestyle Behaviours and Plasma Vitamin $C$ and $\beta$ carotene Levels from The ELAN Population (Liège, Belgium). J Nutr Metab 2011; 2011. doi:10.1155/2011/494370.

23 Mercado-Sáenz S, Ruiz-Gómez MJ, MoralesMoreno F, Martínez-Morillo M. Cellular aging: Theories and technological influence. Brazilian Arch Biol Technol 2010; 53: 1319-1332.

24 Sugianto, Lidyawati N. Pemberian Jus Delima Merah (Punica granatum) dapat Meningkatkan Kadar Glutation Peroksidase Darah pada Mencit (Mus musculus) dengan Aktivitas Fisik Maksimal [Tesis]. Bali: Universitas Udayana; 2011.
25 Sayuti K, Yenrima R. Antioksidan, Alami dan Sintetik. 1st ed. Andalas University Press: Padang, 2015.

26 Beg M, Sharma V, Akhtar N, Gupta A, Mohd J. Role of Antioxidants in Hypertension. J Indian Acad Clin Med 2011; 12.

27 Jannah M, Sulastri D, Lestari Y. Perbedaan Asupan Natrium dan Kalium pada Penderita Hipertensi dan Normotensi Masyarakat Etnik Minangkabau di Kota Padang. J Kesehat Andalas 2013; 2.

28 Putri EHD, Kartini A. Hubungan Asupan Kalium, Kalsium Dan Magnesium Dengan Kejadian Hipertensi Pada Wanita Menopause Di Kelurahan Bojongsalaman, Semarang. J Nutr Coll 2014; 3: 580-586.

29 Sabri L, Hastono SP. Statistik Kesehatan. 2nd ed. PT Raja Grafindo Persada: Jakarta, 2010. 